\title{
Relations of Main-Stem Reservoir Operations and Specific Conductance in the Lower Arkansas River, Southeastern Colorado
}

\section{INTRODUCTION}

Two main-stem reservoirs on the lower Arkansas River, Pueblo Reservoir and John Martin Reservoir, are used to regulate and manage streamflow for irrigation and domestic water supplies, flood control, and recreation. Water storage and release operations for these reservoirs can affect streamflow and water quality of the downstream river. One water-quality property that can be affected is specific conductance. In 1996, the U.S. Geological Survey completed a study of the effects of Pueblo Reservoir and John Martin Reservoir operations on specific conductance at five sites located on the Arkansas River between Pueblo Reservoir and Lamar (fig. 1).
This fact sheet presents an overview of the study findings. A detailed discussion of the study results is presented in Lewis and Brendle (1998).

\section{Specific Conductance and Dissolved Solids}

Specific conductance, in microsiemens per centimeter at 25 degrees Celsius $(\mu \mathrm{S} / \mathrm{cm})$, is a property of water that is attributable to salinity, or dissolved solids, which is a measure of salts such as sodium chloride or calcium bicarbonate. Pure water has a very low specific conductance-a few hundredths of a microsiemen per centimeter. As the dissolved-solids concentration of water increases, the specific conductance increases (fig. 2).

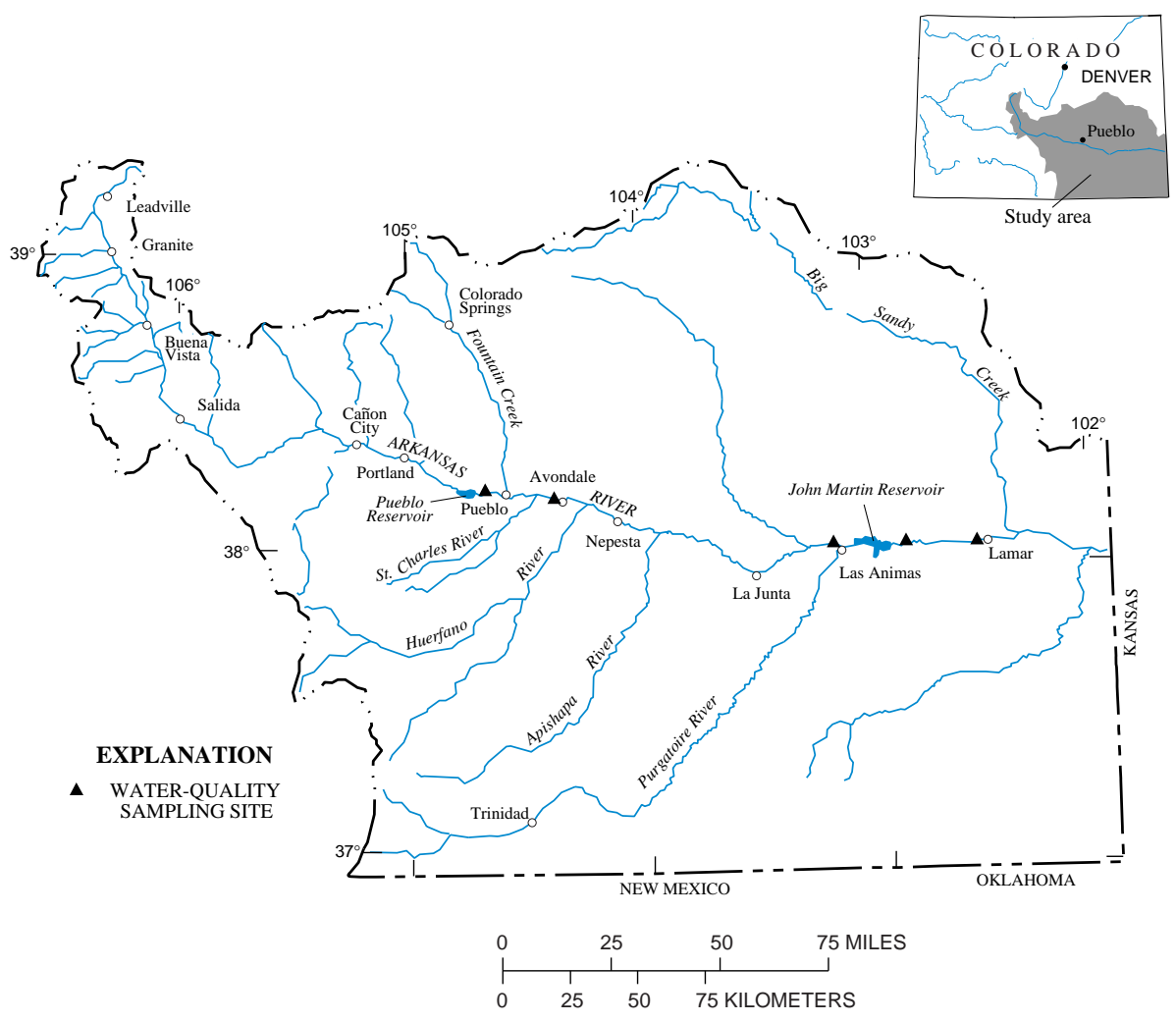

Figure 1. Location of study area.

\section{Specific Conductance Can Affect Water Suitability}

High specific conductance indicates high dissolved-solids concentration; dissolved solids can affect the suitability of water for domestic, industrial, and agricultural uses. The secondary maximum contaminant level for dissolved solids in drinking water is 500 milligrams per liter (mg/L) (U.S. Environmental Protection Agency, 1986). In the lower Arkansas River, $500 \mathrm{mg} / \mathrm{L}$ of dissolved solids is equivalent to a specific conductance of about 700 to $800 \mu \mathrm{S} / \mathrm{cm}$ (Cain, 1987). At higher levels, drinking water may have an unpleasant taste or odor or may even cause gastrointestinal distress. Additionally, high dissolved-solids concentration can cause deterioration of plumbing fixtures and appliances. Relatively expensive water-treatment processes, such as reverse osmosis, are needed to remove excessive dissolved solids from water.

Agriculture also can be adversely affected by high-specific-conductance water. Depending on the crop, agricultural losses might occur when salinity reaches 700 to $850 \mathrm{mg} / \mathrm{L}$ (U.S. Department of the Interior, 1994), which is equivalent to a specific conductance of about 950 to $1,200 \mu \mathrm{S} / \mathrm{cm}$ in the Arkansas River (Cain, 1987). The salinity hazard of irrigation water is a relation developed by the U.S. Salinity Laboratory (Richards, 1954) that describes the qualitative effect of saline water on irrigated crops. The hazard is based on the specific conductance of the water and is divided into four classes of salinity hazard ranging from low (less than $250 \mu \mathrm{S} / \mathrm{cm}$ ) to very high (greater than $2,250 \mu \mathrm{S} / \mathrm{cm}$ ). As specific conductance increases, special agricultural management practices may be needed, and crops having a substantial salinity tolerance may need to be grown. Generally, crops with a higher salinity tolerance have a lower market value than more salt-sensitive crops (Miles, 1977). 


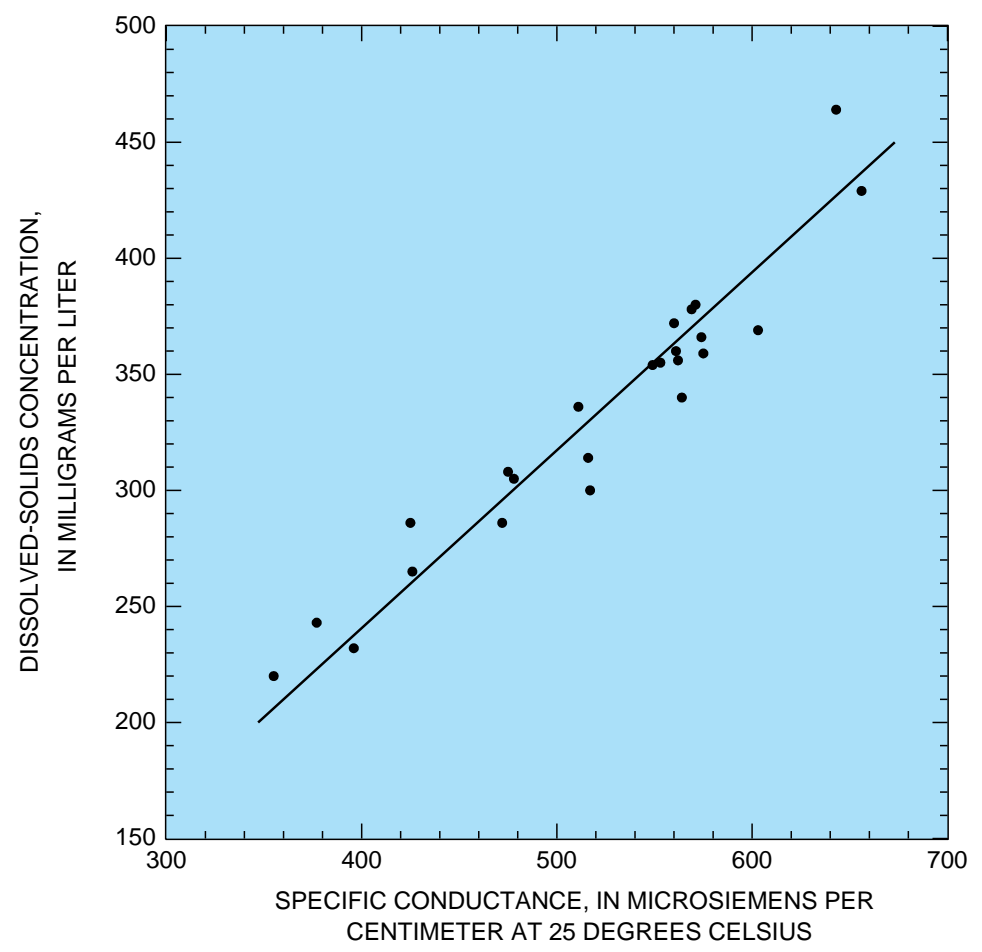

Figure 2. Relation of dissolved-solids concentration to specific conductance in water samples collected in the Arkansas River at Pueblo, 1990-93.

\section{Specific Conductance in the Arkansas River}

The specific conductance of water in the lower Arkansas River markedly increases between Pueblo Reservoir and Lamar, about 160 miles (mi) downstream (fig. 3). Low-specific-conductance snowmelt runoff (generally less than $200 \mu \mathrm{S} / \mathrm{cm}$ ) from the upper Arkansas River Basin is the primary source of streamflow in the lower Arkansas River. Downstream from Pueblo Reservoir, the large increase in specific conductance (fig. 3 ) is attributable to natural and human effects, but the primary cause is the continual use and reuse of water for agricultural irrigation (Cain, 1987). When water is used for irrigation, part of the water evaporates or is consumed by plants, concentrating the original amount of dissolved solids in less water; thus, the dissolved-solids concentration and the specific conductance in the remaining water is increased. The remaining higher specificconductance water reenters the river as irrigation-return flow. The rate of increase in specific conductance in the lower Arkansas River tends to increase downstream because high-specific-conductance irrigation-return flows compose an increasingly large percentage of streamflow (Cain, 1987).

Specific conductance also varies during the year as a result of the temporal variability of streamflow. Specific conductance generally is lowest in May-August, when streamflow generally is largest, and increases with decreasing streamflow in the fall, winter, and spring (fig. 4).

\section{PUEBLO RESERVOIR OPERATIONS}

Storage began in Pueblo Reservoir in 1974, and the dam was completed in 1975 on the main stem of the Arkansas River near Pueblo. The operation of Pueblo Reservoir, in particular the Winter Water Storage Program (WWSP), has a notable effect on streamflow in the lower Arkansas River. The WWSP allows participating irrigation canal companies, which have historically diverted winter flows from the Arkansas River, to store water during the winter in Pueblo Reservoir, in John Martin Reservoir, and in several small off-channel reservoirs. Prior to the WWSP, farmers diverted Arkansas River streamflow onto fallow fields for winter irrigation. This practice was followed to increase soil moisture for later use by crops during the growing season. Winter irrigation is inefficient, however, and the WWSP replaced this practice. Water stored during the winter as part of the WWSP can be released to the river and used by participating canal companies throughout the year at times when natural streamflow is insufficient to meet irrigationwater needs. The WWSP began in 1975 and has been in operation every year since then, except for the 1977-78 winter-storage period. During 1975-94, the median annual volume of WWSP water stored in Pueblo Reservoir was about 42,200 acre-feet (acre-ft) (Thomas C. Simpson, Southeastern Colorado Water Conservancy District, written commun., 1997).

\section{PUEBLO RESERVOIR OPERATIONS HAVE AFFECTED SPECIFIC CONDUCTANCE IN THE ARKANSAS RIVER}

Specific-conductance data collected at three Arkansas River sites located between Pueblo Reservoir and John Martin Reservoir (fig. 1) were analyzed for changes that might have occurred after Pueblo Reservoir was constructed. These three sites are Pueblo, Avondale, and

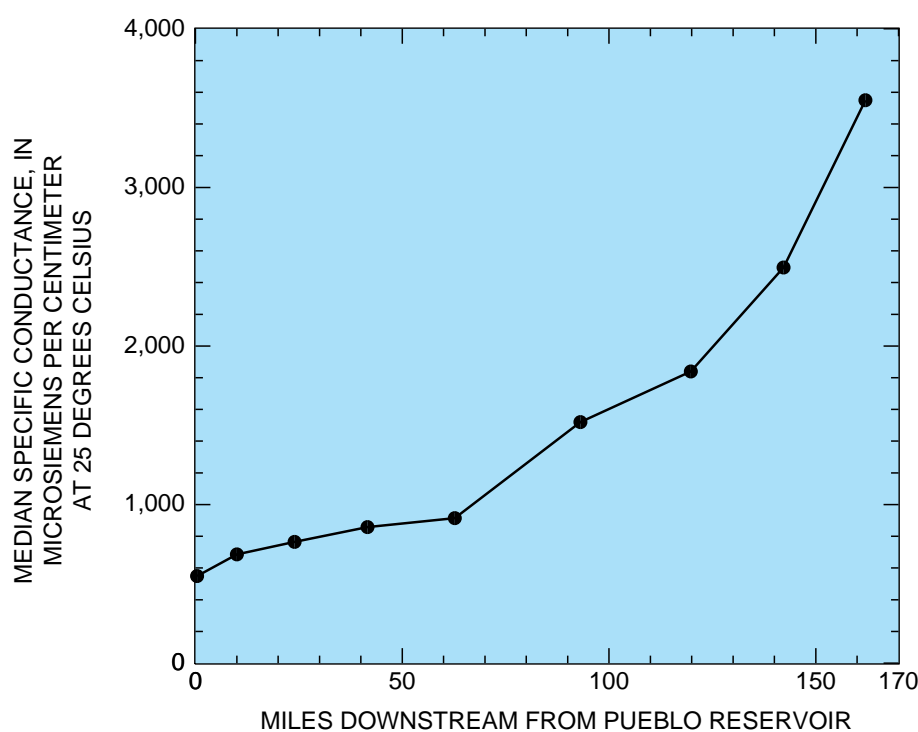

Figure 3. Median specific conductance in the Arkansas River, 1990-93. 


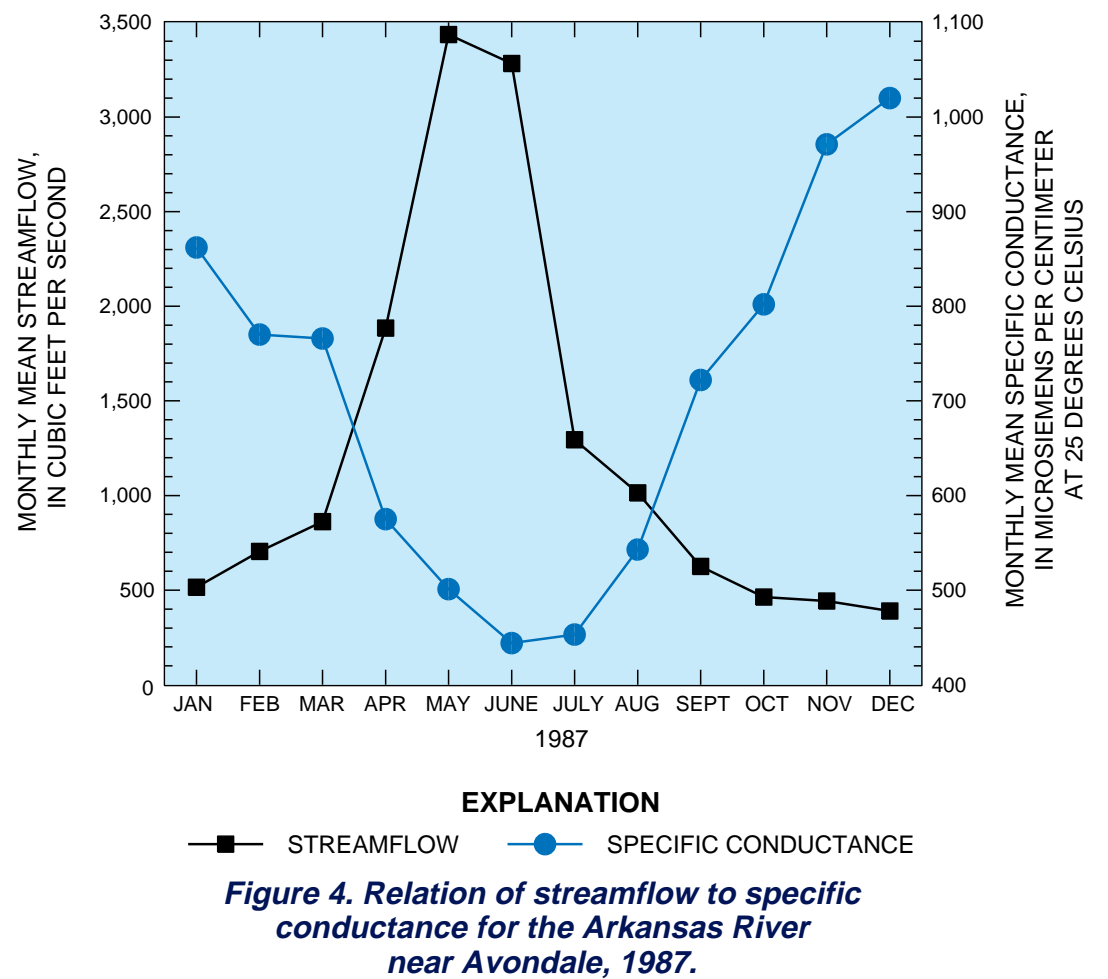

Las Animas. Data collected at each site were separated into two seasons: growing season (March 16-November 14) and winter-storage season (November 15March 15). Data collected prior to 1975 were compared to data collected from 1975 through 1994. At individual stations, the record for specific-conductance data generally was shorter than the record for streamflow. Therefore, the streamflow record for individual stations was shortened to match the specific-conductance record for that station. This matching of records facilitated the direct comparison of streamflow and specific-conductance trends at individual stations.

\section{Arkansas River Above Pueblo}

After construction of Pueblo Reservoir, streamflow in the Arkansas River upstream from Pueblo increased during the growing season and decreased during the winter-storage season, largely due to the effects of the WWSP. Because specific conductance tends to be inversely proportional to streamflow, specific conductance at this site would be expected to increase during the winter-storage season and decrease during the growing season. The opposite occurred. The median specific conductance increased slightly from 460 to $465 \mu \mathrm{S} / \mathrm{cm}$ between 1966-74 and 1975-94 during the growing season and decreased substantially from 720 to $575 \mu \mathrm{S} / \mathrm{cm}$ during the winter-storage season (fig. 5). values after 1974

\section{Arkansas River Near Avondale}

After construction of Pueblo Reservoir, streamflow near Avondale increased during the growing season and decreased during the winter-storage season. The decreased winter streamflow was caused by storage of WWSP water in Pueblo Reservoir. The increase in streamflow during the growing season partly is attributable to the release of WWSP water from Pueblo Reservoir. Increased inflow from Fountain Creek (fig. 1) also accounts for some of the increased streamflow. Population growth in the Colorado Springs area and the associated increase in unit runoff and wastewater discharge are partly responsible for the increase in the median annual streamflow of Fountain Creek at Pueblo, which increased from about 37,000 acre-ft per year in 1969-74 to about 67,000 acre-ft per year in 1975-94.

Specific conductance near Avondale changed appreciably after 1974 (fig. 6), but the changes were different from the changes observed at the site upstream from Pueblo (fig. 5). Between 1969-74 and 1975-94, the median specific conductance increased from 580 to $700 \mu \mathrm{S} / \mathrm{cm}$ during the growing season and increased from 900 to $1,060 \mu \mathrm{S} / \mathrm{cm}$ during the winter-storage season (fig 6).

The combined effect of reservoir operations, as observed at the site upstream from Pueblo, and an increase in the inflow of dissolved solids from Fountain Creek apparently caused the changes in specific conductance near Avondale. Although specific conductance in Fountain Creek decreased after 1974, it remained substantially higher than in the Arkansas River near Avondale. The increase in

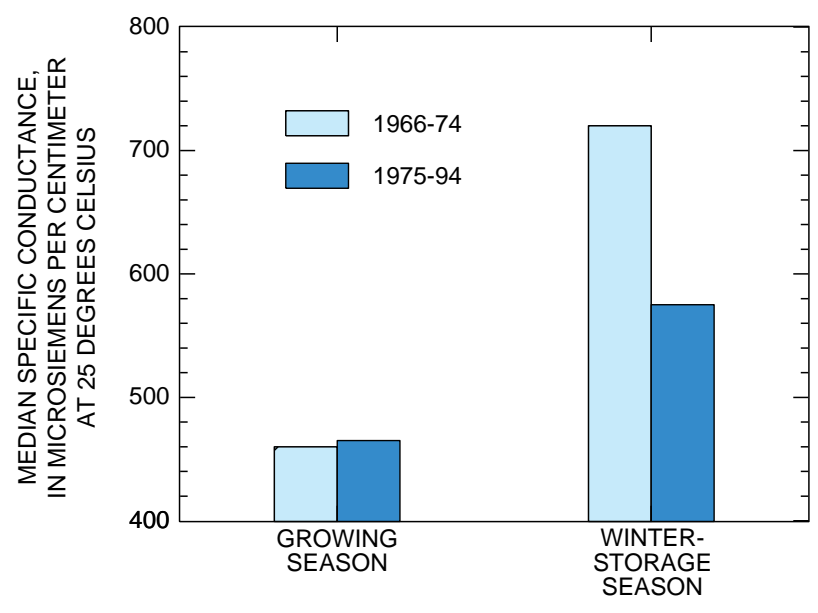

Figure 5. Specific conductance for the Arkansas River above Pueblo, 1966-94. 


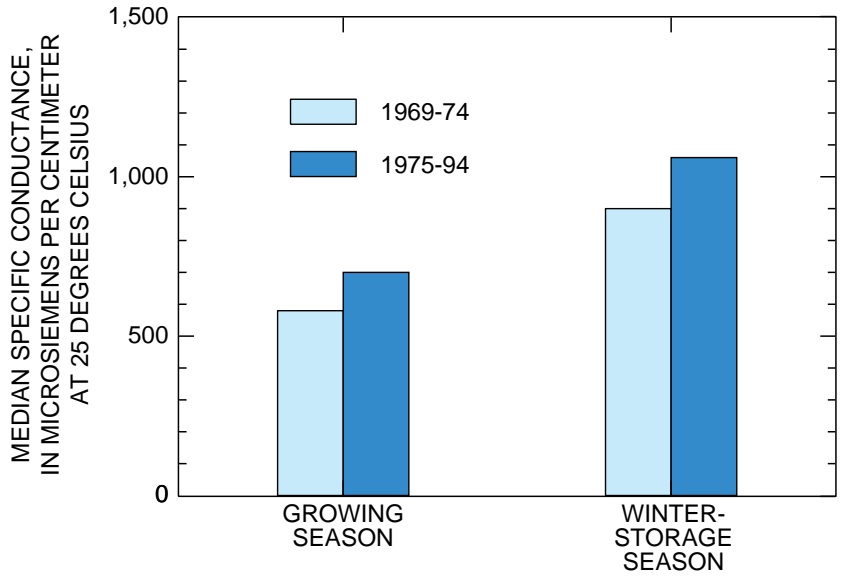

Figure 6. Specific conductance for the Arkansas River near Avondale, 1969-94. streamflow combined with the high specific conductance in Fountain Creek resulted in an estimated 58-percent increase in the dissolved-solids load contributed to the 1975-94. Pueblo Reservoir operations decreased streamflow in the Arkansas River during the winter-storage season. As a result, the increased dissolved-solids load from Fountain Creek was subject to less dilution at the site near Avondale; therefore, specific conductance increased during the growing season between 1969-74 and 1975-94 (fig. 6). During the growing season, specific conductance in the reservoir outflow increased and the dissolved-solids load from Fountain Creek increased, which combined to increase specific conductance near Avondale.

\section{Arkansas River at Las Animas}

Streamflow at Las Animas is substantially smaller than at the upstream sites above Pueblo and near Avondale. The downstream decrease in streamflow is attributable to irrigation diversions upstream from Las Animas. Much of irrigation-return flow (Cain, 1987). After 1974, streamflow at Las Animas increased substantially in every month. The increase in streamflow at Las Animas probably was caused by a combination of factors, including the WWSP and associated changes in seasonal irrigation practices and the increased importation of Colorado River Basin water for irrigation. Prior to the construction of Pueblo Reservoir and the beginning of the WWSP, most winter streamflow was diverted and consumed upstream from Las Animas. With the adoption and full implementation of the WWSP and the increased use of transmountain water for irrigation, streamflow Arkansas River between 1969-74 and the streamflow at Las Animas is from at Las Animas increased significantly. Prior to 1978 , about 14 percent of the annual streamflow at the upstream end of the lower basin flowed past Las Animas. After 1978, that percentage increased to about 26 percent.

The increase in streamflow at Las Animas increased the dilution potential and resulted in substantial decreases in specific conductance between 1961-74 and 1975-94 (fig. 7). The median specific conductance decreased during the growing season from $2,820 \mu \mathrm{S} / \mathrm{cm}$ in $1961-74$ to 2,250 $\mu \mathrm{S} / \mathrm{cm}$ in 1975-94 (fig. 7). Similarly, the median specific conductance decreased during the winter-storage season from $3,300 \mu \mathrm{S} / \mathrm{cm}$ in $1961-74$ to $2,730 \mu \mathrm{S} / \mathrm{cm}$ in 1975-94 (fig. 7). The increase in streamflow and dilution potential at Las Animas apparently was large enough to offset the increasing specific-conductance trend in the Arkansas River measured farther upstream near Avondale.

\section{JOHN MARTIN RESERVOIR OPERATIONS}

John Martin Reservoir was completed in 1948 on the main stem of the Arkansas River between Las Animas and Lamar. Storage of irrigation water in John Martin Reservoir is by agreement between the States of Colorado and Kansas, under the Arkansas River Compact, which was signed in 1948. The Compact ensures that both States receive their percentage shares of Arkansas River flows (Abbott, 1985).

The Compact dictates a winter- and a summer-storage period. During the winterstorage period, November 1 to March 31, most of the reservoir inflow is stored. Prior to 1980, provisions were made for the release of stored water, without reference to the volume of stored water assigned to each State. To ensure that each State received its share of stored water, release demands by each State were made concurrently. Although the Compact was to ensure that Colorado and Kansas irrigators received their legal shares of Arkansas River water, it did not "result in the most efficient utilization possible of the water in its control" (Arkansas River Compact Administration, 1980, p. 40). Prior to 1980, after the winterstorage period, reservoir storage usually was drawn down to empty or almost empty very early in the irrigation season, often by the middle of April (fig. 8). From 1955 through 1979, reservoir storage was completely depleted by April 30 in 15 of the 25 years.

To help alleviate the problems associated with historical reservoir operations, a new reservoir operating plan was adopted in 1980 (Arkansas River Compact Administration, 1980). Under the new plan, water not immediately called for and released to downstream irrigators

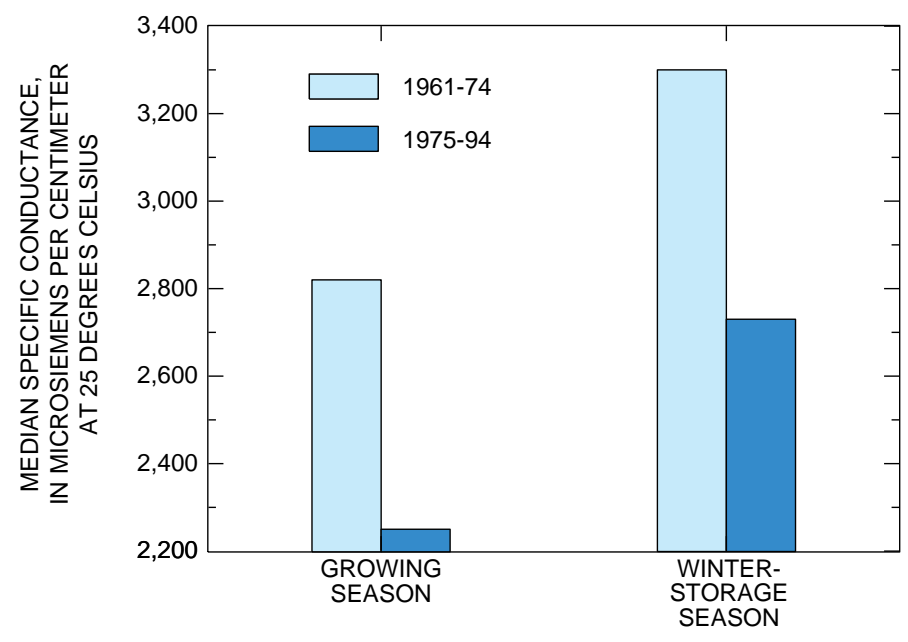

Figure 7. Specific conductance for the Arkansas River at Las Animas, 1961-94. 


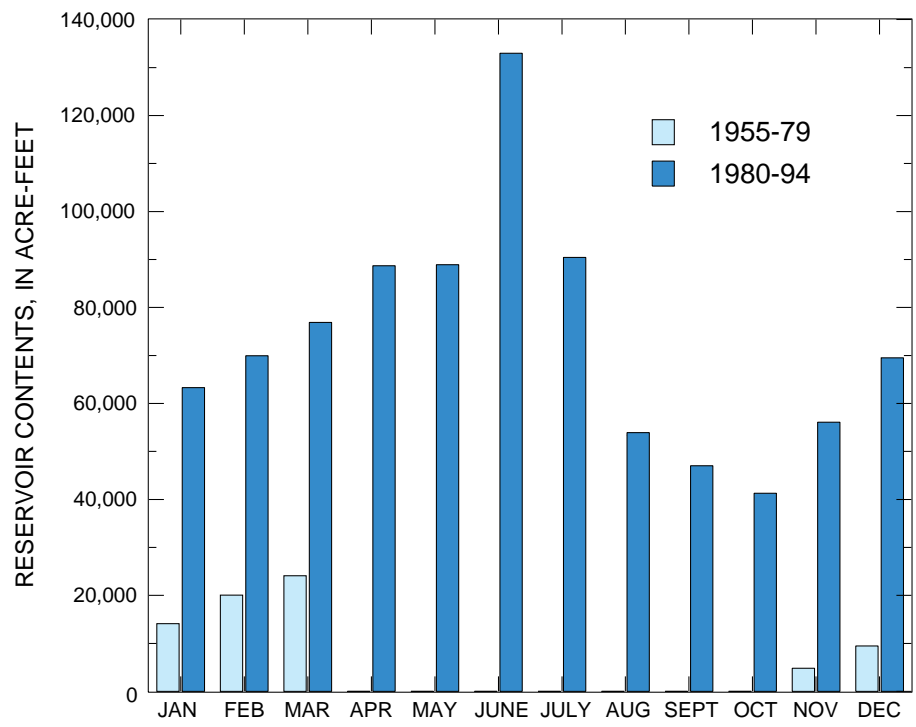

Figure 8. Median end-of-month contents of John Martin Reservoir, 1955-79 and 1980-94.

was stored in separate storage accounts for Colorado and Kansas. One State can call for the release of its stored water independently of the other State. This change in operating practices generally resulted in downstream irrigators waiting until later in the irrigation season to release their stored water to the river; therefore, the 1980 operating plan has probably contributed to increased storage in John Martin Reservoir (fig 8). Storage of water in John Martin Reservoir also has benefited from increased inflow, as noted in the "Arkansas River at Las Animas" section. At Las Animas, located about 3 mi upstream from the reservoir, median annual streamflow of the Arkansas River increased 142 percent from 76,400 acre-ft in $1955-79$ to 185,200 acre-ft in 1980-94.

\section{JOHN MARTIN RESERVOIR OPERATIONS HAVE AFFECTED SPECIFIC CONDUCTANCE IN THE ARKANSAS RIVER}

Specific-conductance data from two Arkansas River sites located downstream from John Martin Reservoir (fig. 1) were analyzed for changes that might have occurred after the adoption of the 1980 operating plan. These two sites are downstream from John Martin Reservoir and at Lamar. Data collected at each site were separated into two seasons: growing season (April 1-October 31) and winter-storage season (November 1March 31). Data collected prior to 1980 were compared to data collected from 1980 through 1994.

\section{Arkansas River Below John Martin Reservoir}

After the adoption of the 1980 operating plan, streamflow at the site downstream from John Martin Reservoir increased substantially during the growing season and decreased slightly during the winter-storage season. The largest increase in the daily mean streamflow for any month was in July; the daily mean streamflow increased from 490 cubic feet per second $\left(\mathrm{ft}^{3} / \mathrm{s}\right)$ in $1955-79$ to $878 \mathrm{ft}^{3} / \mathrm{s}$ in 1980-94. The overall increase in streamflow for 1980-94 was attributable to increased inflow into the reservoir and subsequent reservoir releases. In addition to increased inflow, a large increase in streamflow during the middle of the growing season probably was attributable to the new operating plan, which allows downstream irrigators to release the stored water later in the growing season rather than at the very beginning of the growing season.

Specific conductance changed appreciably after the implementation of the 1980 operating plan (fig. 9). During the growing season, the median specific conductance decreased from $2,180 \mu \mathrm{S} / \mathrm{cm}$ in $1955-79$ to $2,050 \mu \mathrm{S} / \mathrm{cm}$ in 1980-94. During the winter-storage season, the median specific conductance decreased substantially from $3,650 \mu \mathrm{S} / \mathrm{cm}$ in $1955-79$ to $2,640 \mu \mathrm{S} / \mathrm{cm}$ in $1980-94$. The overall decrease in specific conductance was a result of two main factors. The first was decreased specific conductance in the reservoir inflow, as indicated at the Las Animas site. At Las Animas, the median specific conductance for the growing season decreased from $2,655 \mu \mathrm{S} / \mathrm{cm}$ in 1961-79 to $1,855 \mu \mathrm{S} / \mathrm{cm}$ in $1980-94$, and the median specific conductance for the winter-storage season decreased from $3,500 \mu \mathrm{S} / \mathrm{cm}$ in $1964-79$ to $2,710 \mu \mathrm{S} / \mathrm{cm}$ in $1980-94$.

The second factor was increased reservoir inflow and reservoir storage and a corresponding increase in mixing of seasonally low-specific-conductance water and seasonally high-specific-conductance water in the reservoir; thus, the range in specific conductance narrowed after 1980.

\section{Arkansas River at Lamar}

Changes in streamflow and specific conductance measured at the Lamar site were very similar to changes at the site downstream from John Martin Reservoir. Streamflow at Lamar increased substantially during the growing season; the largest increases occurred during July. However, streamflow also increased slightly during the winter-storage season.

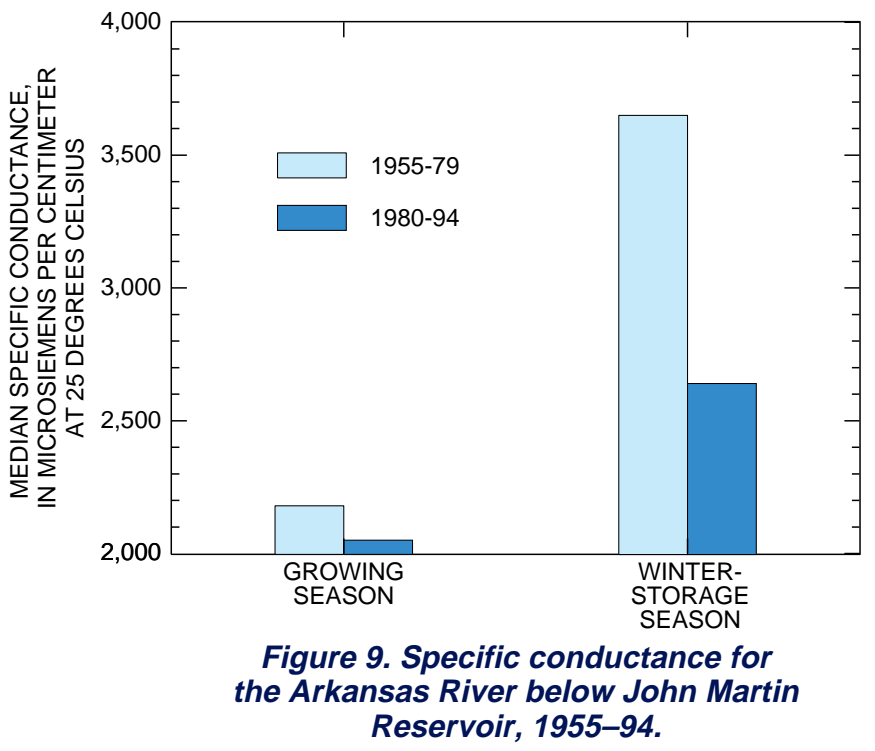




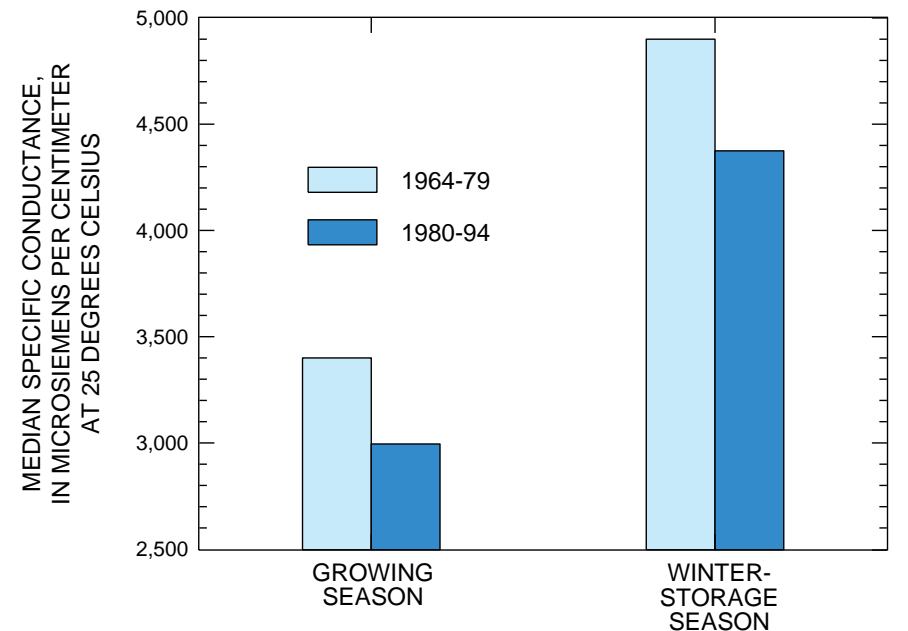

Figure 10. Specific conductance for the Arkansas River at Lamar, 1964-94.

During the growing season, the median specific conductance decreased from $3,400 \mu \mathrm{S} / \mathrm{cm}$ in $1964-79$ to $2,995 \mu \mathrm{S} / \mathrm{cm}$ in $1980-94$ (fig. 10). During the winter-storage season, the median specific conductance decreased from $4,900 \mu \mathrm{S} / \mathrm{cm}$ in $1964-79$ to $4,375 \mu \mathrm{S} / \mathrm{cm}$ in 1980-94 (fig. 10). In addition to increased winter streamflow downstream from the reservoir and an associated increase in the dilution potential of the river, the same factors that affected specific conductance at the site downstream from John Martin Reservoir probably caused the changes in specific conductance at Lamar.

\section{CONCLUSIONS}

An analysis of historical specificconductance data indicates that specific conductance in the Arkansas River changed as the result of main-stem reservoir operations. Specific conductance upstream from Pueblo and at Las Animas tended to decrease following the construction of Pueblo Reservoir. Likewise, specific conductance downstream from John Martin Reservoir and at Lamar decreased after implementation of the 1980 John Martin Reservoir operating plan. The decrease in specific conductance at the site upstream from Pueblo is beneficial from a municipal drinking-water-supply perspective because streamflow in this area provides drinking water to the greater Pueblo area. Although specific conductance increased at the site near Avondale, the increase after 1974 was not large enough to change the salinity hazard for irrigated agriculture. Although specific conductance decreased at Las Animas, downstream from John Martin Reservoir, and at Lamar, the decrease was not large enough to change the salinity hazard for irrigated agriculture. The salinity hazard at all three sites remained high to very high (greater than 2,250 $\mathrm{S} / \mathrm{cm}$ ).

\section{REFERENCES}

Abbott, P.O., 1985, Description of watersystems operations in the Arkansas River Basin, Colorado: U.S. Geological Survey Water-Resources Investigations Report 85-4092, 67 p.

Arkansas River Compact Administration, 1980, Thirty-second annual report: Lamar, Colorado, $50 \mathrm{p}$.

Cain, Doug, 1987, Relations of specific conductance to streamflow and selected water-quality characteristics of the Arkansas River Basin, Colorado: U.S. Geological Survey Water-Resources Investigations Report 87-4041, 93 p.

Lewis, M.E., and Brendle, D.L., 1998, Relations of streamflow and specificconductance trends to reservoir operations in the lower Arkansas River, southeastern Colorado: U.S. Geological Survey Water-Resources Investigations Report 97-4239, 48 p.

Miles, D.L., 1977, Salinity in the Arkansas Valley of Colorado: Denver, U.S. Environmental Protection Agency and Colorado State University, Interagency Agreement, EPA-IAG-D4-0544, 80 p.

Richards, L.A., ed., 1954, Diagnosis and improvement of saline and alkali soils: Washington, D.C., U.S. Department of Agriculture Handbook 60, $160 \mathrm{p}$.

U.S. Department of the Interior, 1994, Salinity update: Denver, Bureau of Reclamation, 17 p.

U.S. Environmental Protection Agency, 1986, Secondary maximum contaminant levels (section 143.3 of part 143, National secondary drinking-water regulations): U.S. Code of Federal Regulations, Title 40, Parts 100-149, p. 587-590.

This study was conducted in cooperation with the Colorado Springs Utilities; Pueblo Board of Water Works; Southeastern Colorado Water Conservancy District; Pueblo County, Department of Planning and Development; city of Aurora, Department of Utilities; St. Charles Mesa Water District; Upper Arkansas Area Council of Governments; Upper Arkansas Water Conservancy District; city of Pueblo, Department of Utilities; Pueblo West Metropolitan District; Fremont Sanitation District; and the cities of Rocky Ford, Las Animas, and Lamar.

-Michael E. Lewis, Water Resources Division, Pueblo, CO

Information on technical reports and hydrologic data related to this study can be obtained from:

Subdistrict Chief

U.S. Geological Survey

201 West 8th Street, Suite 200

Pueblo, CO 81003

(719) 544-7155, ext. 130 